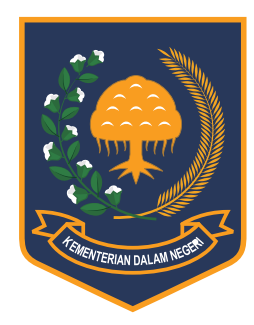

JURNAL BINA PRAJA

e-ISSN: 2503-3360 | p-ISSN: 2085-4323

Accreditation Number

21/E/KPT/2018

http://jurnal.kemendagri.go.id/index.php/jbp/index

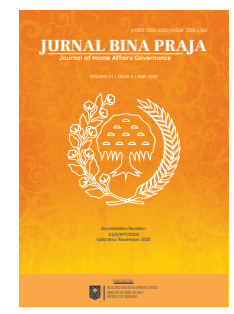

\title{
The Management Model of Aceh's Special Autonomy Fund
}

\author{
Safrizal Zakaria Ali \\ Ministry of Home Affairs of the Republic of Indonesia
}

Received: 10 June 2019; Accepted: 20 September 2019; Published online: 8 November 2019

DOI: $10.21787 /$ jbp.11.2019.159-170

\begin{abstract}
The Aceh Special Autonomy Fund, better known as DOKA, was established in 2008. The amount of DOKA increases significantly every year. However, the increase was not followed by an increase in the local economy. As such, there was no significant improvement in the welfare of the people of Aceh. Therefore, this paper seeks to examine the Aceh Special Autonomy Fund's Management Model. This paper was using qualitative method through FGD, interviews, and documentation. The results of this study showed the need to improve the performance of the Asymmetric Decentralization Policy through Special Autonomy in Aceh Government such as 1) completion of the drafting of implementing regulations; 2) establish a proactive communication and build trust; 3) socialization by the Ministry of Home Affairs related to the Law on Aceh Government (UUPA) in relation to the Law on Oil and Gas, free trade and others; 4) drafting of guidelines in the implementation of special autonomy; 5) facilitates the division of authority between the Aceh Provincial Government and its district/city governments. The recommendation from this study is to list the division of authority of government affairs in detail between the Aceh Provincial Government and its district/city governments, by considering of the characteristics and aspirations of the regions to avoid disputes over authority and overlapping authority.
\end{abstract}

Keywords: Asymmetric Decentralization Policy, Aceh Special Autonomy Fund (DOKA), Management Model.

\section{INTRODUCTION}

Asymmetric decentralization is the grant of special authority in certain areas in a country as an alternative to resolve various relationship problems between the central government and regional governments. The main characteristic of Aceh's asymmetric decentralization is its special nature and special authority of Aceh in the broad sense (Kurniadi, 2012, p. 121). The manifestation of its special nature and special authority was set forth explicitly in Law Number 11 of 2006 on the Aceh Government, or widely known as the UUPA. The UUPA stipulates that, Aceh is a provincial region led by a Governor which is a special legal community unit and is given special authority to self-regulate and manage its own government affairs and the interests of local communities in accordance with laws and regulations in the system and principles of the Unitary State of the Republic of Indonesia based on the 1945 Constitution of the Republic of Indonesia. One form of Aceh's privileges according to Warouw et al., (2016, p. 628) and (Anwar; Adi Rosita Dwi; Abdullah, M Faisal; Hadi $(2018$, p. 9) is the provision of special autonomy funds to the Aceh Government (known as DOKA), which is regulated in Article 179. Article 179 Paragraph (2) letter c of the law states that one of the revenues for Aceh Province and Districts is from the Special Autonomy Fund (Otsus). Article 183 of the law states that the Special Autonomy Fund, as referred to in Article 179 paragraph (2) letter $c$, is the revenue of the Aceh Government earmarked for financing the construction and maintenance of infrastructures, empowering the people's economy, alleviating poverty, education, social and health.

It is interesting to study the implementation of the asymmetric decentralization policies in Aceh in the form of special autonomy funds for several reasons. First, DOKA is mandated by the law which aims to accelerate the improvement of the welfare of the people of Aceh. DOKA, as a follow up to Law No. 11 of 2006 on Aceh Government (UUPA), is regulated in Article 183 Paragraph (1) UUPA and Article 10 Qanun No. 2 of 2008 on the Procedures for the Allocation of Additional Funds from Oil and Gas Revenues. The UUPA mandates

\footnotetext{
* Corresponding Author

Phone : +62 8129312626

Email : safrizalza70@gmail.com
} 
Table 1.

Comparison of the Economic Growth of Aceh and Other Provinces in Sumatera (2012-2017)

\begin{tabular}{lllllllllll}
\multicolumn{1}{c}{ Provinces } & $\mathbf{2 0 1 2}$ & $\mathbf{2 0 1 3}$ & $\mathbf{2 0 1 4}$ & $\mathbf{2 0 1 5}$ & $\mathbf{2 0 1 6}$ & $\mathbf{2 0 1 7}$ & $\mathbf{2 0 1 7 * *}$ & $\mathbf{2 0 1 7 * * *}$ & Average - All Provinces \\
Aceh & 3.85 & 2.61 & 1.55 & -0.72 & 3.31 & 3.40 & 3.75 & 4.10 & 2.73 \\
\hline North Sumatera & 6.45 & 6.07 & 5.23 & 5.08 & 5.18 & 4.50 & 5.11 & 5.21 & 5.35 \\
\hline West Sumatera & 6.31 & 6.08 & 5.86 & 5.52 & 5.26 & 4.99 & 5.33 & 5.38 & 5.59 \\
\hline Riau & 3.76 & 2.48 & 2.70 & 0.22 & 2.23 & 2.83 & 2.41 & 2.85 & 2.44 \\
\hline Jambi & 7.03 & 6.84 & 7.35 & 4.20 & 4.37 & 4.25 & 4.32 & 4.76 & 5.39 \\
\hline Riau Islands & 7.63 & 7.21 & 6.62 & 6.01 & 5.03 & 2.02 & 1.04 & 2.41 & 4.75 \\
\hline South Sumatera & 6.83 & 5.31 & 4.68 & 4.42 & 5.03 & 5.14 & 5.26 & 5.56 & 5.28 \\
\hline Bengkulu & 6.83 & 6.07 & 5.47 & 5.13 & 5.30 & 5.23 & 5.13 & 4.83 & 5.50 \\
\hline Lampung & 6.40 & 5.77 & 5.08 & 5.13 & 5.15 & 5.13 & 5.03 & 5.12 & 5.35 \\
\hline Bangka Belitung Islands & 5.50 & 5.20 & 4.68 & 4.08 & 4.11 & 6.40 & 5.29 & 3.69 & 4.87 \\
\hline Average - Sumatera & $\mathbf{6 . 0 6}$ & $\mathbf{5 . 3 6}$ & $\mathbf{4 . 9 2}$ & $\mathbf{3 . 9 1}$ & $\mathbf{4 . 5 0}$ & $\mathbf{4 . 3 9}$ & $\mathbf{4 . 2 7}$ & $\mathbf{4 . 3 9}$ & 4.72 \\
\hline
\end{tabular}

Source: Badan Pusat Statistik, 2017

*Quarter 1, ** Quarter 2, *** Quarter 3

that DOKA is utilized to finance the construction and maintenance of infrastructure, empowering the people's economy, alleviating poverty, and provide funding for education, social and health. The UUPA also mandates that the DOKA be allocated to finance programs related to the implementation of Aceh's privileges.

Second, DOKA allocation by the central government increases significantly in the 10 years (2008 - 2018), reaching more than 59 Trillion Rupiah, more than enough to accelerate Aceh's development. However, various studies have shown that the Special Fund is unable to increase the welfare of the people of Aceh (I. D. I. Cahyono, 2011, p. 2). DOKA disbursement increases significantly every year, from 3.590 Trillion Rupiah in 2008 to 5.476 Trillion Rupiah in 2012 and continue to increase to 8.30 Trillion Rupiah in 2018 (ZA, 2019 p.373). However, the increase has not shown any impact on the improvement of Aceh economy. In the last five years, the growth of Aceh economy is only $2.73 \%$ per year on average. This is the secondlowest growth in Sumatera area (BPS, 2017), as described in Table 1.

The increase of DOKA disbursement is not in line with the region's ability to grow its own revenue source. It can be seen from the DOKA contribution of 59.2 percent of the total revenue of the region (Table 2). On the other hand, the Region Own-source Revenue (PAD) is only 14.39 percent. It indicated that Aceh fiscal independence is low.

Third, DOKA is for a limited time, as stipulated in UUPA Article 183 Paragraph (2), which is only for 20 years. The amount of DOKA is $2 \%$ of the General Allocation Grant (Dana Alokasi Umum Nasional/ DAUN) for the first fifteen years (2008 - 2022) and $1 \%$ of DAUN for the next four years (2023 - 2028). Ideally, with such a limited time, Aceh Government's activities should be more focus and well-planned to reap the benefit of DOKA. DOKA should be managed effectively while avoiding problems and externalities, which negatively affect the result of asymmetric decentralization in Aceh.

This study focused on the implementation of DOKA by First, review the current management of DOKA, Second, identify regulations related to DOKA, and Third, formulate a model which optimized the management of DOKA. Several researchers have examined various aspects of the regional autonomy fund, such as a study by Nadir,(2013) on regional autonomy and village decentralization. While Putra, (2014, p. 421) discussed Welfare Improvement Through DOKA and Annafie \& Nurmandi (2017) which discussed the special autonomy institution of 
Table 2.

Proportion of Aceh's Total Revenue (2012-2017)

\begin{tabular}{|c|c|c|c|c|c|c|c|}
\hline \multirow{2}{*}{ Type of Revenue } & \multicolumn{6}{|c|}{$\%$ to Total Revenue } & Average \\
\hline & 2012 & 2013 & 2014 & 2015 & 2016 & 2017 & (\%) \\
\hline Region Own-Source Revenue (PAD) & 9.82 & 12.42 & 14.92 & 16.88 & 16.66 & 15.90 & 14.43 \\
\hline Fiscal Balance Fund & 25.71 & 25.07 & 21.99 & 13.37 & 12.72 & 26.57 & 20.90 \\
\hline Special Autonomy Fund & 59.65 & 58.31 & 58.80 & 60.42 & 62.33 & 55.69 & 59.20 \\
\hline Other Aceh's Revenues & 4.82 & 4.20 & 4.30 & 9.32 & 8.29 & 2.10 & 5.50 \\
\hline Total & 100.00 & 100.00 & 100.00 & 100.00 & 100.00 & 100.00 & 100.00 \\
\hline
\end{tabular}

Source: Aceh Government 2012 - 2017 Financial Reports (processed)

the Special Region of Yogyakarta.

A study on DOKA also conducted by H. Cahyono (2016, p. 1) by using a qualitative analysis method. The study found that the special autonomy fund does not have an impact on the welfare of the people of Aceh. Generally, there was no improvement in the condition of the people. Ironically, the improvement of welfare is enjoyed by a small number of people close to the circle of power, resulting in the Nouveau Riche phenomenon. Another study discussing the Special Autonomy Fund is Nurhemi (2015, p. 183) which discussed the Impact of the Region's Financial Autonomy to the Growth of Indonesian Economy. This study concluded that financial autonomy (represented by the degree of fiscal decentralization) has a positive impact on economic growth. However, in the sub-sample of each region, the positive impact of the PCI (Per Capita Income) on growth was only valid in Java and Bali for a long observation period (1990-2011). This finding leads to the conclusion that the impact of fiscal decentralization on economic growth is not conclusive for decentralization in Indonesia.

Another study (Suharyo, 2012, p. 324) examine the effectiveness of DOKA from the legal perspective. This study found that the lack of attention on the inefficiencies of the Special Autonomy Fund which lead to the inability to reduce the level of poverty is overshadowed by the dispute over the symbols of Aceh, such as the flag, symbol, and anthem. Kompak (2018) evaluated the use of the Special Autonomy Fund using a qualitative method by conducting FGD with Aceh's Stakeholders. The study found that the Special Autonomy Fund is not used effectively: 1) The Special Autonomy Fund is not focused on funding programs/activities with a large and long- term impact; (2) The Master Plan for the Utilization of the Special Autonomy Fund for 2008-2027 has only been prepared in 2015, with the issuance of the Regulation of the Governor of Aceh Number 78 of 2015, rendering it ineffective as a guideline in directing the utilization through various programs and activities that have a wide impact on improving the economy and welfare of the people of Aceh.

A study by Olasupo $(2013$, p. 207) examined a local government autonomy crisis in Nigeria where the government is unclear and uncertain, leading to a problem in measuring regional autonomy. Anyebe (2017, p. 41) started the study on special autonomy. It showed that the local government in Nigeria were not in-line with the classical theoretical position, and it may be due to the prolonged military rule and undemocratic attitude of the state governors who treat that level of government as an extension of their country.

Another study on special autonomy in the field of governance is Anggraini, (2009, p. 26) which focused on the direct election of the regional head and its vice head in the special autonomy of the province of Nangroe Aceh Darussalam. This study used a qualitative method and discussed the legal framework for the direct election of the head and the vice head of Aceh in connection to the implementation of Law No. 8 of 2001 on Special Autonomy for the province of Aceh Special Region as the Province of Nangroe Aceh Darussalam. The result of this study was that the election of the regional head in Aceh must be seen from the spirit of the special autonomy. Another study by Ghitulescu, (2009, p. 1) reviewed conceptual and theoretical issues to show the theoretical point of view in the division of asymmetric power in a federal country. 
The researcher compared decentralization and division of power theories and see it from the context of the United States of America.

Another study by (Ibrahim, 2008, p. 5) stated that the regional regulations are a very complicated process. It is laden with political interactions although there are rules of laws governing it. A combination of the rules of law and a relatively democratic political configuration should result in suitable regional regulations. However, there were plenty of regional regulations in East Java province that are problematic. Other studies review it from a management perspective (Habibi, 2015, p. 124). A study by Hillman (2012, p. 439) explained that Partai Aceh won by a landslide in the 2009 legislative election. The study featured in-depth interviews with the national and non-national political parties in Indonesia, including Papua, where the failure of the special autonomy rules lead to the increased militancy of the indigenous Papuan.

The previous studies mainly examine the impact of the special autonomy fund on the region's economy and welfare from a specific point of view, such as from political view and conceptual view. In this study, the researcher reviewed the problem of managing the special autonomy fund, starting from the management, identification of the DOKA management problem and recommended a suitable management model. To the best of the researcher's knowledge, there has been no study on the implementation of the Special Autonomy Fund by examining the existing regulation and formulate an effective management model to optimize the use of the Special Autonomy Fund to achieve the objective of the asymmetric decentralization (Setiawan, 2018).

This study is important and relevant since it shows a current portrait of Indonesia. Article 294 in Law No. 23 of 2014 on Regional Government and its derivative regulations makes this study more important to be carried out to provide input on policy formulation by the Ministry of Home Affairs, especially in the management of special autonomy funds. Also, the inclusion of the special autonomy issue as a spatial based issue makes this topic very relevant for a study object. The study discussed: first, the dynamics of DOKA management, second, DOKA management regulations, and third, suggest the Special Autonomy Fund management model in Aceh Government to improve the quality of the implementation of asymmetric decentralization policies in Aceh Government.

\section{METHOD}

The qualitative design was chosen to answer the objective of the study (Denzin \& Ryan, 2007, p. 576). The qualitative approach was chosen based on the consideration that this was a case study. Case studies are a research strategy, an empirical study that investigates a phenomenon in a reallife setting (Strauss \& Corbin, 1994, p. 273). This strategy can include qualitative evidence that relies on various sources and prior developments from theoretical propositions. This study used interviews, observations, and documentation methods for data collection (Rubin, Allen; Babbie, 2011, p. 389). This method was chosen because the researcher valued the conversation between the source and the interviewer. The objective of the interview was to get the right information from trusted sources. Interviews were conducted by posing several questions to the sources selected using purposive sampling method. The sampling criteria of the sources were officials from the central government, regional governments, and Aceh Government, academician, public figure, customary leaders, and local media who are familiar with DOKA. Primary and Secondary data were gathered (Neuman, 2014 , p. 36). Primary data was gathered through FGD, interviews and secondary data was gathered from documentation review and other relevant supporting data. A descriptive method was used to process and analyze the data. The descriptive method was chosen since this study aimed to describe a current symptom, event, and phenomena (Naod \& Ritzer, 2001, p. 24). A Descriptive study focused its attention to current problems happening during the study, to describe the facts and nature of a specific population or area in a systematic, factual, and accurate way. After the data was gathered, it was classified into 2 (two) type of data, the qualitative and quantitative data. Qualitative data, in the form of words or sentences, was collated into themes to be analyzed further to reach a conclusion (Bryman, 2012 , p. 212). Quantitative data in the form of numbers were processed by calculating, adding, or turn into a percentage, and then described.

\section{RESULTS AND DISCUSSION}

\section{A. DOKA Management}

Tarlton (1965 p. 5) started the discussion on asymmetric decentralization by stating that the main difference between the symmetric and the asymmetric decentralization was in the form of conformity and commonality in a level of government (state/regions) with the general system of government, central government or between 
state/regional governments. It means, that the symmetric decentralization showed a symmetrical relationship between each state or between the regional government and the central government, with each has the same number or the same power of authority. Or as he stated, "the level conformity and commonality in the relations of each separate political unit of the system to both the system as a whole and the other components units". While in the asymmetric decentralization, one or more units of the regional government "posed of varying degrees of autonomy and power".

In the relationship between the central government and the regional government in DOKA management, the asymmetric decentralization means that the central government grants the regional government (Aceh) the freedom to manage its own financial matters. One of the financial resources for Aceh and its districts/ cities is the Aceh Special Autonomy Fund (Dana Otonomi Khusus/DOKA). Although it was stated as the source of revenue for the region, district/cities, DOKA was not directly disbursed to the district/ city governments. It was disbursed through Aceh Provincial Government. Article 183 of the law states that the Special Autonomy Fund as referred to in Article 183 paragraph (1) letter c is the revenue of the Aceh Government earmarked for financing the construction and maintenance of infrastructures, empowering the people's economy, alleviating poverty, education, social and health.

However, there were disputes between the district government and the provincial government in the management of DOKA. The districtgovernment proposed that the management of DOKA should not be dominated by the provincial government. As referred to in the UUPA, the provincial government 'administered" the special autonomy fund, and as such, from the view of the district government, the special autonomy fund should be disbursed directly to the accounts of the district/city governments and managed in a quite independently by the district/city government. However, the provincial government argued that the special autonomy fund should be managed by the provincial government. This is because, first, the special autonomy status is granted in the province level, not in the level of the district/city. That is why the special autonomy is referred to as the Aceh Government Special Autonomy, not the Pidie District Special Autonomy, Bener Meriah Special Autonomy, or others. Second, since the special autonomy status is in the province level, then the provincial government should be the one responsible for the use of the special autonomy fund. As such, the management of the fund should be in the province level, it will be quite a risk to hand over the management completely to the district/city while the province must be responsible for its use.

Due to those reasons, during a period of the study (in 2018), a new draft of Qanun was proposed, which, govern that the disbursement of the Special Autonomy Fund was in the form of a transfer to the district/city. Referring to Article 183 paragraph (4) UUPA, the Aceh Provincial Government is the receiver of the Special Autonomy Fund from the central government, to be used to finance the development programs including in districts/ cities. The Special Autonomy Fund is also the revenue of the district/city government. As such, to use the Special Autonomy Fund for the district/ city development programs, the Aceh Government transferred the Special Autonomy Fund to the districts/cities for the agreed-upon development programs in infrastructure, community economy improvement, poverty alleviation, education, social, and health.

There are some articles in UUPA which may have multiple interpretations. For example, article 179 of the law states that one of Aceh Province and its districts/cities revenue is from the Special Autonomy Fund (Otsus). However, article 183 of the law states that the Special Autonomy Fund as referred to in Article 179 paragraph (2) letter c is the revenue of the Aceh Government earmarked for financing the construction and maintenance of infrastructures, empowering the people's economy, alleviating poverty, education, social and health. The interpretation of that article is that the special autonomy fund should be disbursed to the Aceh Government first and may not be directly disbursed by the central government to the district government.

While referring to article 179 of UUPA, the special autonomy fund may be directly disbursed to the district/city. Article 179 UUPA indicated that the special autonomy fund may be directly managed by the district/city governments.

Third, another issue on the Special Autonomy Fund for the districts/cities was related to the Excess of Annual Budget (Sisa Lebih Pembiayaan Anggaran Tahun Berkenaan/SILPA) in Qanun No. 2 of 2008 on The Allocation Process of the Special Autonomy Fund, which stated that $60 \%$ of the Special Autonomy Fund shall be allocated for the districts and $40 \%$ for the province. However, whenever there was an excess of budget (SILPA), it was also treated as the province revenue (APBA). The districts / city governments think that the SILPA should be returned to the districts/city, it can be used to complete the work that was delayed or that had not been completed in the current year and would be budgeted again in the following year. 
Such non-synchronous regulations between the UUPA and the Qanun Aceh Number 2 of 2008 on The Procedure for the Allocation of Additional Oil and Gas Revenue Sharing Funds and the Use of Special Autonomy Funds should not have happened if there is the same understanding of the procedures for utilizing special autonomy funds. The demand for revision and adjustment to the legal requirements to accelerate the improvement of the welfare of the people of Aceh is inevitable. This Qanun caused some problems: first, it affirms that DOKA is the revenue for the Aceh provincial Government only. Second, the budget allocations to the districts/cities are not provided in the form of cash funds, but in the form of budget figures that are set annually by the governor after it is approved by the Leaders of DPRA. Third, the six development program areas and activities must refer to the Aceh's and district's/city's LongTerm and Medium-Term Development Plan (RPJP and RPJM) as well as the Aceh Government Work Plan (RKPA), and the City Development Work Plan (RKPK). The problems would be more complicated when the Qanun for RPJP, RPJM, and RKPA is not yet issued. Based on the UUPA, DOKA should focus on 6 (six) areas of development: infrastructure, people's economy, poverty alleviation, education, social and health. The use of DOKA beyond these six fields is not following the UUPA. Therefore, it has the potential to be a violation of the special autonomy fund allocation regulation and may be prosecuted.

Fourth, DOKA is only available for a limited time frame (20 years) as stipulated in Article 183 Paragraph (2) UUPA. The amount of DOKA is $2 \%$ of the General Allocation Grant (Dana Alokasi Umum Nasional/DAUN) for the first fifteen years (2008 - 2022) and 1\% of DAUN for the next four years (2023 - 2028). Ideally, within the limited time limit, the Aceh Government should be more focused and have a better plan to use this opportunity effectively. Therefore, the use of DOKA for the six development programs above must be clear and focused in accordance with the RPJM and RPJP of the Aceh and district/city stated in the Qanun.

Fifth, Article 183 paragraph (5) UUPA states, the use of DOKA is carried out for each fiscal year that is regulated further in the Qanun. Every activity that would be funded by DOKA should be listed in Aceh's Qanun on APBA, and then it would be allocated for special assistance for the districts/cities.

Issues on DOKA management also influenced the relationship between the Central Government and Aceh Governments (province and district/city governments) and between the Aceh Governor and district/city governments, creating an unharmonious relationship between the provincial government and district/city governments. The authority over DOKA management has created a problem between Aceh district heads/mayors and the Governor of Aceh.

Based on the provisions of Article 183 paragraph (4) of the UUPA, DOKA is utilized for provincial and district/city development programs. The utilization of DOKA must ensure the balance of development progress in each district/city, which is managed by the Aceh Province Government. The word "and" that connects the phrase provincial and district/city development in Aceh means that the Aceh development program utilizing the Special Autonomy Fund is implemented by the Aceh Government. Meanwhile, district/city development programs financed by the Special Autonomy funds are implemented by the district/city government.

The revenues of Aceh Province and its districts/ cities consist of the Regional Revenue and Financing Revenue. The Regional Revenue stem from Region Own-Source Revenue (PAD), Regional Fiscal Balance Fund (Dana Perimbangan), Special Autonomy Fund, and other revenues. The UUPA stated that the revenue from Aceh and the districts/ cities came from the special autonomy fund. The sources of the Region Own-Source Revenue (PAD) of Aceh Province and its districts/cities consist of regional tax, regional levy, the income from the management of the province's/districts'/cities' resources and the income from the province's/districts'/cities' investment; zakat and other own-source revenues.

The Regional Fiscal Balance Fund as referred to UUPA Article 179 paragraph (2) letter $b$, the fund consists of Revenue Share of Tax income (90\%) from the Land and Building Tax, $80 \%$ of share from the Conveyance Tax (BPHTB); and $20 \%$ of share from Income Tax (article 25, 29 and 21).

Other revenues are Revenue Sharing Fund from hydrocarbon and other natural resources, General Allocation Fund (Dana Alokasi Umum/DAU) and Special Allocation Fund (Dana Alokasi Khusus/ DAK). Revenue Sharing Fund from hydrocarbon and other natural resources are forestry ( $80 \%$ share), fisheries (89\% share), general mining (80\% share), geothermal resources ( $80 \%$ share), oil (15\% share); and $30 \%$ revenue share from natural gas fields.

With the enactment of Law Number 11 of 2006 on the Aceh Government, in addition to the Special Autonomy Fund, Aceh also received Additional Revenue Sharing Funds (TDBH) from oil and gas sector (55\% of oil and $40 \%$ of natural gas). The revenue sharing fund is intended to be used to improve the welfare of the people of Aceh, ensuring there are balanced developments in the various districts/cities and considering the contribution of the region producing the revenue. Based on Qanun Number 2 of 2008, oil and gas producing 
Table 3.

Fiscal Balance Fund in UUPA

\begin{tabular}{llc}
\multicolumn{1}{c}{ Type of Revenue } & \% according to UUPA \\
& Aceh (\%) & $\begin{array}{c}\text { Government } \\
\text { (\%) }\end{array}$ \\
\hline Land and Building Tax (PBB) & 90 & 10 \\
\hline Conveyance Tax & 80 & 20 \\
\hline Revenue from the Forestry Sector & 80 & 20 \\
\hline Revenue from the Mining Sector & 80 & 20 \\
\hline Revenue from the Fishery Sector & 80 & 20 \\
\hline Personal Income Tax & 20 & 80 \\
\hline Oil Resources & 80 & 30 \\
\hline Natural Gas Resources & 70 & 30 \\
\hline Geothermal Resources & 70 & 20 \\
\hline Geothermal Resources & 80 & 20 \\
\hline
\end{tabular}

Source: processed from UUPA, 2018

regions received an additional $25 \%$ allocation of revenue sharing from the 70 percent of Additional Revenue Sharing Fund after deducting 30\% of it for the education funds. Areas that are not oil and gas producers receive a budget allocation of 35 percent, as illustrated in Table 3.

In addition to Revenue Sharing Funds, the Aceh Government receives additional oil and gas Revenue Sharing Funds amounted to 55\% share of oil revenue; and $40 \%$ share of natural gas revenue.

The UUPA stipulated that the DOKA is to be used to fund the development and maintenance of infrastructure, empowering the people's economy, alleviating poverty, and provide funding for education, social and health for 20 years since 2008 . In the first 15 years, Aceh Province received $2 \%$ of the General Allocation Fund (DAU) budget nationally, and for the 16 th to 20 th years the amount was $1 \%$ of the General Allocation Fund (DAU) nationally. This is a fixed formula, means that if the State Budget (APBN) increases, the Special Autonomy Fund will also increase. Of course, following the objectives of the DOKA, an increase in DOKA must also be accompanied by economic growth in Aceh so that the improvement of the welfare of the local community can be achieved.

Therefore, it is necessary to formulate the use of a special autonomy fund that is in accordance with the UUPA. The Aceh Government, with the approval of the DPRA, has issued Aceh Qanun Number 2 of 2008 on the Procedures for the Allocation of Additional Oil and Gas Revenue Sharing Funds and the Use of Special Autonomy Funds, which shall take effect on January 22, 2008. This Qanun regulates the distribution of the allocation of Special Autonomy Funds between the provincial government and district/city governments.

\section{B. DOKA Management Regulation}

DOKA management is regulated by Qanun Number 2 of 2008. DOKA Management is centralized at the Provincial level. The Provincial Government is responsible for the administration, allocation, implementation, and supervision of programs funded through the DOKA. The Provincial Government has the authority over 40 percent of the Special Autonomy Fund and the remaining 60 percent for the district/city governments.

The UUPA is the basis for the management of the Special Autonomy Fund by the Aceh Government and the district/city governments. Article 179 Paragraph (2) letter c of the law states that one of Aceh Province and Districts revenue is from the Special Autonomy Fund. Article 183 of the law states that the Special Autonomy Fund as referred to in Article 179 paragraph (2) letter c is the revenue of the Aceh Government earmarked for financing the construction and maintenance of infrastructures, empowering the people's economy, alleviating poverty, education, social and health. The management of the Aceh Special Autonomy Fund is regulated in the Qanun as a follow-up to Law No. 11 of 2006 on the Aceh Government.

The Qanun has undergone several changes during the ten fiscal years (2008-2019) of the implementation of the Special Autonomy Fund:

\section{1) Qanun No. 2 of 2008 (2008-2013)}

In this period, the management of the Qanun by the Aceh Government Work Unit (SKPA), including allocations for districts/cities, where the Budget User Authority (KPA) and the Technical Implementation Activities Officer (PPTK) reside with the Aceh Apparatus Work Unit (SKPA). Then from 2010 to 2013, district/city governments were given greater authority. Budget implementation is carried out by the district/city, while the KPA and PPTK were in the District/City Apparatus Work Unit (SKPK).

\section{2) Qanun No. 2 of 2013 (2014-2018)}

Since 2014, the Special Autonomy Fund governance model has given full authority to 
Table 4.

DOKA Allocation Pattern

\begin{tabular}{lccl}
\hline Period & \% for District/City & $\%$ for Province & \multicolumn{1}{c}{ Legal Basis } \\
\hline 2008 - 2013 period & $0 \%$ & $100 \%$ & $\begin{array}{l}\text { Aceh Qanun Number } 2 \text { of } 2008 \text { on the Procedures for Allocation of Additional } \\
\text { Funds for Oil and Gas Revenue Sharing and Use of Special Autonomy Funds }\end{array}$ \\
\hline 2013 - 2017 period & $40 \%$ & $60 \%$ & $\begin{array}{l}\text { Aceh Qanun Number } 2 \text { of } 2013 \text { on the amendment of Aceh Qanun Number } 2 \\
\text { of } 2008 \text { on the Procedures for Allocation of Additional Funds for Oil and Gas } \\
\text { Revenue Sharing and Use of Special Autonomy Funds }\end{array}$ \\
\hline 2018 - now & $0 \%$ & $100 \%$ & $\begin{array}{l}\text { Aceh Qanun Number } 10 \text { of 2016 on the second amendment of Aceh Qanun } \\
\text { Number 2 of 2008 on the Procedures for Allocation of Additional Funds for Oil } \\
\text { and Gas Revenue Sharing and Use of Special Autonomy Funds (40\% in the form } \\
\text { of activity programs in Aceh districts/cities) }\end{array}$ \\
\hline
\end{tabular}

Source: Directorate General of Financial Supervision of the Ministry of Home Affairs, 2018.

district/city governments through a special direct transfer mechanism based on Qanun 2 of 2013 which is an amendment to Qanun Number 2 of 2008.

\section{3) Qanun No. 10 of 2016 (2018)}

With the enactment of Qanun 10 of 2016, since 2018 the Management of DOKA has returned to the Aceh (Provincial) Government. At present, a draft of the Third Amended of Qanun No. 2 of 2003. One of the main substances is to return the mechanism for the distribution of Special Autonomy Funds to districts/cities in the form of special transfer funds.

The 2008 - 2017 Qanuns which regulates the management of the Special Autonomy Fund showed that there are two management patterns. First, a centralized pattern, where management allocation is centralized in the province, the provincial government directly implements the Special Autonomy Fund through the Aceh Apparatus Work Unit (SKPA). Second, the decentralized pattern, that is, funds are transferred (assisted to be disbursed) to all districts/cities.

Based on the discussions with the SKPA (Bappeda, the Regional Financial Management Agency, in Bappeda Office, 15 February 2019 at $15: 30$ to $18: 00$ ), it is known that each of the Special Autonomy Fund management patterns has its strengths and weaknesses. Direct management by the district/city is expected to increase the effectiveness of the budget since the districts/ cities are more aware of their community needs and problems. However, the synergy and synchronization between the districts/cities and the province are not optimal.

On the other hand, the management of the Special Autonomy Fund allocated to the districts/ cities by the Province potentially may be inaccurate and less effective because the Provincial SKPA does not understand the district/city community's needs and problems. Also, if it is managed by SKPA, the district/city governments are not responsible when there is a problem in the implementation of the program, because they do not have the authority to manage the budget. However, management by the Provincial SKPA provides better assurance of the creation of synergy and integrated development across the Aceh districts/cities.

The current management of the Special Autonomy Fund is regulated in Aceh Qanun No. 10 of 2016 on the Second Amendment to Qanun No. 2 of 2008 on the Procedure for the Additional Allocation of Revenue Share Fund of Oil and Gas and the management of the Special Autonomy Fund (presented in Table 2). Referring to Qanun No. 10 of 2016 Article 1 Paragraph (16) letter a, the Special Autonomy Fund is intended to finance the district/ city development programs and activities following Aceh's priorities and stipulated in the APBAceh. The Allocation of the Autonomy Fund is conducted through: (a) for common programs/activities of Aceh Province and district/city governments, the amount is determined annually in the APBA; and (b) $40 \%$ (forty percent) is budgeted for district/city development programs and activities in the form of Special Autonomy Funds (Article 11 Paragraph (1) of UUPA). Special Autonomy Funds are allocated to districts/cities annually based on the proposal of district/city development programs and activities (article 11 paragraph (2) UUPA). Programs and activities are budgeted in the Special Autonomy Fund which is determined annually in the APBA (article 11, paragraph 6).

Based on the provisions of Article 183 Paragraph (4) of the UUPA, the Aceh Provincial Government, as the recipient of the Special Autonomy Fund from the central government, is to 
finance the development programs in the districts/ cities. The special autonomy fund is also revenue for the district/city governments. Qanun Number 2 of 2013 article 11 paragraph (1) letter a, stipulates that $60 \%$ (sixty percent) of the Special Autonomy Fund is allocated to Aceh Province development programs and activities and $40 \%$ (forty percent) is allocated to districts/cities development programs and activities. In addition to the development programs and activities under the authority of the (Province) Aceh Government, a maximum of 1\% (one percent) is allocated for the development of the Capital of Aceh. Furthermore, development funds intended for districts/cities must consider the development progress between districts/cities. The fund allocation for each district/city is determined based on a formula using several indicators such as population, area, Human Development Index (HDI), Construction Expense Index (Indeks Kemahalan Konstruksi/IKK) and other relevant indicators, as regulated in Article 11 Paragraph (3) Qanun number 2 of 2013.

While referring to article 179 of UUPA, the Special Autonomy Fund must be directly disbursed to the district/city. And the provisions of Article 179 of the UUPA are clear that the Special Autonomy Fund may be managed directly by the district/city. Another problem of the Special Autonomy Fund management is relating to the remaining budget (SILPA). In the Qanun No. 2 of 2008 on The Allocation Process of the Special Autonomy Fund, it is stated that $60 \%$ of the Special Autonomy Fund shall be allocated for the districts and $40 \%$ for the province. However, whenever there was an excess of budget (SILPA), it was also treated as the province revenue (APBA). The districts/city governments think that the SILPA should be returned to the districts/city.

This Qanun caused some problems: first, it affirmed that the Special Autonomy Fund is the Aceh Provincial Government's revenue. Second, the budget allocations to the districts/cities are not provided in the form of cash funds, but in the form of budget allocations that are set annually by the governor after it is approved by the Leaders of DPRA. Third, the six development program areas and activities must refer to the Aceh's and district/city Long-Term and Medium-Term Development Plan (RPJP and RPJM) as well as the Aceh Government Work Plan (RKPA) and the District/City Development Work Plan (RKPK). The problems would be more complicated when the Qanun for RPJP, RPJM, and RKPA is not issued yet. Based on the UUPA, DOKA should focus on 6 (six) areas of development: infrastructure, people's economy, poverty alleviation, education, social and health. The use of DOKA beyond these six fields is not in accordance with UUPA. Therefore, it has the potential to become a violation of/criminal case on the Special Autonomy Fund Allocation. Third, DOKA is only for a limited time (20 years), as stipulated in UUPA Article 183 Paragraph (2). The amount of DOKA is $2 \%$ of the General Allocation Grant (Dana Alokasi Umum Nasional / DAUN) for the first fifteen years (2008 - 2022) and 1\% of DAUN for the next four years (2023 - 2028). Ideally, with the limited time, the Aceh Government should be more focused and have a better plan to use this opportunity effectively. Therefore, the use of DOKA for the six development programs above must be clear and focused, in accordance with the RPJM and RPJP of the Aceh and district/city stated in the Qanun. Fifth, Article 183 paragraph (5) UUPA states, DOKA disbursement is carried out for each fiscal year that is regulated further in the Aceh Qanun. Every activity that would be funded by DOKA should be listed in Aceh Qanun on APBA, and then it would be allocated for special assistance for the districts/cities.

\section{DOKA Management Model}

Although the Special Autonomy Fund allocation is divided between the allocations for the provinces and districts/cities (Table 6.38), the fund management is divided into two patterns. First, the centralized management in the Province, where the provincial government directly implements the Special Autonomy Fund through the SKPA. Second, the decentralized management, funds are transferred (assisted to be disbursed) to all districts/cities.

Each type has its strengths and weaknesses. Direct management by the district/city is expected to increase budget effectiveness since the districts/ cities are more aware of their community needs and problems. However, the synergy and synchronization between the districts/cities and the province are not optimal. On the other hand, the management of the Special Autonomy Fund allocated to the districts/cities by the Province through SKPA has the potential to be inaccurate and less effective because the SKPA does not understand the community's needs and problems in the district/ city. Also, if it is managed by SKPA, then when there is a problem in the implementation of the program, the district/city governments are not responsible because they do not have the authority to manage the budget. However, management by the Provincial SKPA provides better assurance of the creation of synergy and integrated development across the Aceh districts/cities.

This finding is in line with the previous study conducted by (I. D. I. Cahyono, 2011, p. 72) which 


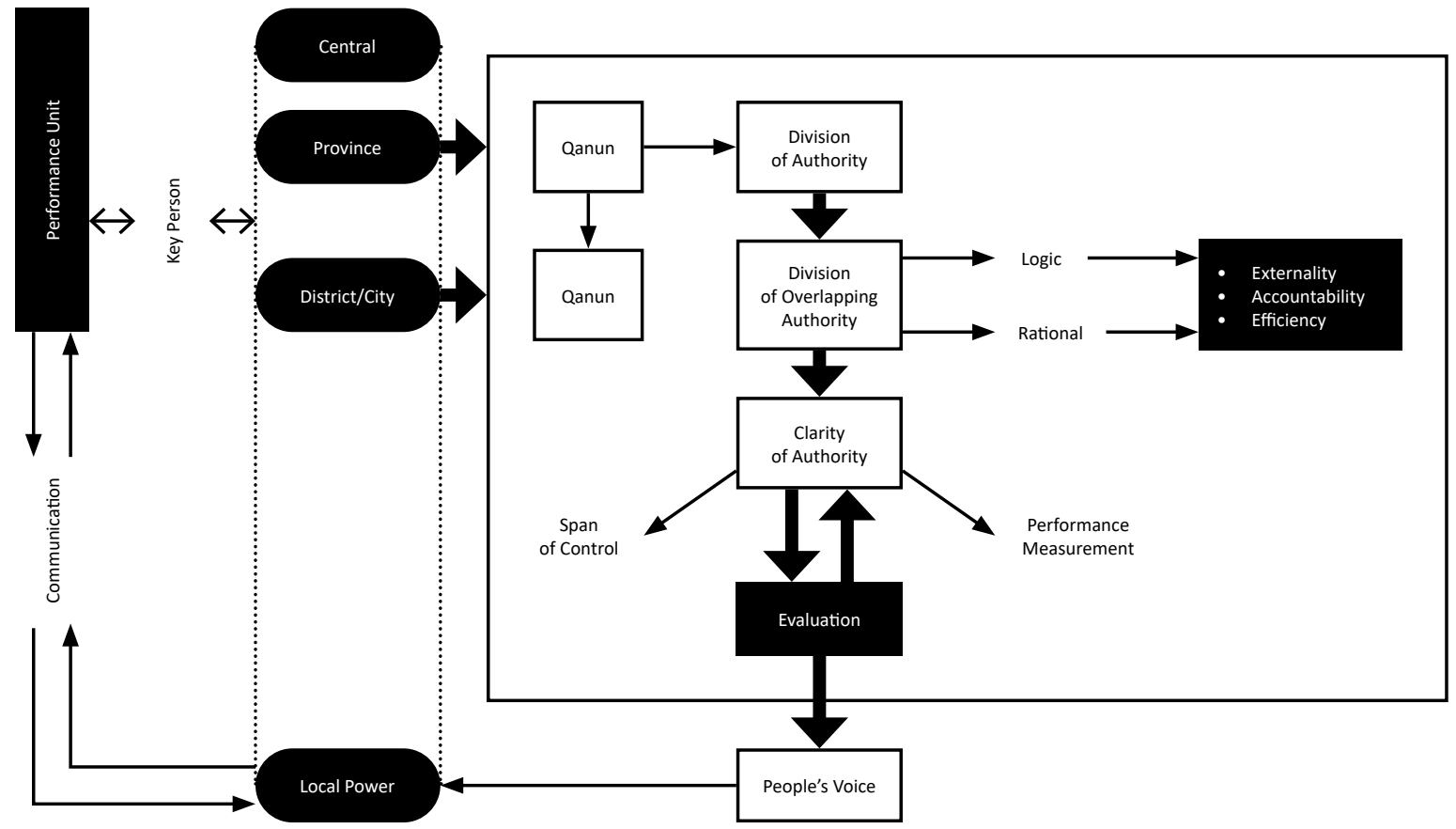

Figure 1. The Management Model of Aceh's Special Autonomy Fund

states that the management of the special autonomy fund has led to a prolonged dispute between the Governor and the district heads/mayors. Districts/ Cities want the Special Autonomy Fund to be transferred directly and managed by the district/ city. Another problem that arises relating to the management of special autonomy funds by SKPA is the management of assets from the fund allocated for the districts/cities. Capital expenditures in the form of fixed assets managed by the district/city must go through a grant process from the province to the district/city. In practice, this process is not easy, the administrative process is long and often exceeds one fiscal year. The grant process for the fixed assets are needed, otherwise, these assets would not be managed and maintained in the future. The proposed improvements of the Special Autonomy Management model are as illustrated in Figure 1.

First, the Aceh Government and its district/ city governments need to prepare a Qanun on the division of authority between provinces and city/ districts. The Special Autonomy is placed at the provincial level, but its area coincides with the district/city areas, as such the potential for overlap is very likely. Some special authorities are inherently shared between provinces, districts, and cities. For this reason, a clear division of authority is needed. So, it can be used for the preparation of actions and programs, financing, controlling and performance measurement. It is also necessary to have these two levels for honest, rational, and logical calculations to determine which functions are the authority of which level. The preparation of parameters in advance will be very helpful in performing careful analysis. The parameters that are often used in the distribution of authority in symmetrical decentralization (externalities, accountability, and efficiency) can be used, aside from other specific factors such as the disparity between regions, customs, and others.

Second, the Aceh Government needs to appoint a capable and permanent key person to communicate with the central government, at least the person concerned can help to describe the situation at hand and creating cohesive information. The same is true for providing explanations and influencing the district/city governments and the importance of synergy in achieving the objectives of the special autonomy.

Third, the provincial and district governments need to build a joint performance unit to "attack" the common goals that must be achieved. Partial achievement without an integrated effort can only be possible if all indicators have shown some progress, but if sub-performance indicators are bad then the integration of planning, budgeting, and implementation will be crucial in achieving the desired results.

Fourth, the Aceh Government and the city districts need to prepare a reliable evaluator to monitor and match the program objectives, activities as well as the performance results. The evaluator can immediately inform the regional head of the deviation, unrealized target, or a gap between 
the plan and its implementation. Work methods can be innovated with an application model so that the evaluation process can be conducted every time, saving cost, and responsive to developments. The evaluator can also be the one gathering people's aspirations and can provide alternative information to the leadership on the community's needs and monitor the community's views and attitudes towards the development process.

Fifth, it needs a very strong ability to communicate with the local power structure, such as DPRA and other bodies that have a significant role in policy implementation. The influence of local parties that form factions in the DPRA is quite strong because of its majority and influence. Convincing them to buy into the planned road map is very important for the success of Aceh.

\section{Conclusion}

The results of this study are the first: The implementation of DOKA through the special autonomy has a significant impact on the political aspects of governance, especially on the stability of security, however, it is not significantly improved Aceh's economy. Second, regulations concerning the DOKA did not have an adequate division of authority in government management between the Aceh Province and its district/city governments. Third, a better model in the management of DOKA is to accommodate the characteristics and aspirations of the region so that there is no dispute and overlapping authority. As such, the legal consequences and consistency can be present to maintain the stability of development for a just and prosperous society. This study recommends an improvement of the division of authority in government affairs between the Aceh province government and the district/city governments to accommodate the characteristics and aspirations of the region so that there is no dispute and overlapping authority, so that the legal consequences and consistency can be present to maintain the stability of development for a just and prosperous society.

\section{ACKNOWLEDGMENT}

The author would like to thank the Head of R\&D Center, the Governor of Aceh, and Prof. Dr. Murtir Jeddawi, SH, Dr Sampara Lukman MA, Prof. Dr. Aries Djaenuri, M.A. Prof. Dr Ngadisah, MA, Prof Dr. Djohermansyah Djohan, MA and Researchers at Balitbang of the Ministry of Home Affairs Adi Suhendra, M.Sosio, who have provided many valuable inputs for this article.

\section{REFERENCES}

Anggraini, T. (2009). Pemilihan Kepala Daerah dan Wakil Kepala Daerah Langsung dalam Kerangka Otonomi Khusus Provinsi Naggroe Aceh Darussalam. Universitas Indonesia.

Annafie, K., \& Nurmandi, A. (2017). Kelembagaan Otonomi Khusus (Otsus) Dalam Mempertahankan Nilai-Nilai Kebudayaan Di Provinsi Daerah Istimewa Yogyakarta. Journal of Governance and Public Policy, 3(2), 304-338. https://doi. org/10.18196/jgpp.2016.0061

Anwar; Adi Rosita Dwi; Abdullah, M Faisal; Hadi, S. (2018). Analisis Pengaruh Pendapatan Asli Daerah, Dana Otonomi Khusus Dan Belanja Modal Terhadap PDRB Di Kab/Kota Provinsi. Jurnal Ilmu Ekonomii, 2, 1-13.

Anyebe, A. A. (2017). An Overview of Local Government Autonomy and its Functions in Nigeria. Greener Journal of Social Sciences, 7(4), 041-044. https://doi.org/10.15580/ GJSS.2017.4.082717110

Bryman, A. (2012). Social Research Methods (Fourth Edi). New York: Oxford University Press.

Cahyono, H. (2016). EVALUASI ATAS PELAKSANAAN OTONOMI KHUSUS ACEH: GAGAL MENYEJAHTERAKAN RAKYAT DAN SARAT KONFLIK INTERNAL. Jurnal Penelitian Politik, 9(2), 1-22.

Cahyono, I. D. I. (2011). Permasalahan Otonomi Khusus di Aceh dan Papua: Sebuah Makalah Inisiatif Strategi. Jakarta.

Cheema, G. S. D. A. R. (2007). Decentralizing Governance: Emerging Concepts and Practices. Washington: Brookings Institution Press.

Denzin, N. K., \& Ryan, K. E. (2007). Qualitative Methodology (Including Focus Groups). In W. Outhwaite \& S. P. Turner (Eds.), The SAGE Handbook of Social Science Methodology Chapter (pp. 578-595). SAGE Publications Ltd. https://doi.org/http://dx.doi. org/10.4135/9781848607958

Ghitulescu, M. (2009). The Idea of Asymmetric Power Dispersion: Conceptual Issues. Politics and Administration Journal.

Habibi, M. M. (2015). Analisis Pelaksanaan Desentralisasi Dalam Otonomi Daerah Kota/Kabupaten. Jurnal Pendidikan Pancasila Dan Kewarganegaraan, 3(2), 117-124. https://doi. org/10.1016/0014-4894(54)90048-X

Hillman, B. (2012). Ethnic politics and local political parties in Indonesia. Asian Ethnicity, 13(4), 419-440. https://doi.org/10.1080/14631369. 2012.710078

Ibrahim, A. (2008). Legislasi Dalam Perspektif Demokrasi : Analisis Interaksi Politik dan Hu- 
kum dalam Proses Pembentukan Peraturan Daerah di Jawa Timur. Universitas Diponegoro. Kurniadi, B. D. (2012). Desentralisasi Asimetris. Politik Dan Pemerintahan, 1-11.

Nadir, S. (2013). Otonomi Daerah dan Desentralisasi Desa. Jurnal Politik Profetik, 1(1). https://doi. org/10.24252/jpp.v1i1.1621

Naod, J., \& Ritzer, G. (2001). Modern Sociological Theory. Teaching Sociology. https://doi. org/10.2307/1318728

Neuman, W. L. (2014). Social Research Methods: Qualitative and Quantitative Approaches (Seventh Ed). Harlow: Pearson Education Limited.

Nurhemi, G. S. R. (2015). Dampak Otonomi Keuangan Daerah Terhadap Pertumbuhan Ekonomi Di Indonesia. Buletin Ekonomi Moneter Dan Perbankan, 18(2, oktober), 183-206. Retrieved from www.bi.go.id/.../Dampak Otonomi Keuangan Daerah Terhadap Pe...\%0A

Olasupo, F. A. (2013). The Scope and Future of Local Government Autonomy in Nigeria. Advances in Applied Sociology, 03(05), 207-214. https:// doi.org/10.4236/aasoci.2013.35028

Putra, E. J. (2014). Mewujudkan Kesejahteraan Melalui Dana Otonomi Khusus Aceh dalam Perspektif Hukum Keuangan Negara. Jurnal Ilmu Hukum, 16(64), 421-435.

Rubin, Allen; Babbie, E. (2011). Research Methods for Social Work. Belmont: Linda Schreiber.
ZA, Safrizal. (2019). Disertasi: Implementasi Kebijakan Desentralisasi Dalam Penyelenggaraan Pemerintahan Aceh. Jakarta: Institut Pemerintahan Dalam Negeri

Setiawan, I. (2018). Handbook Pemerintahan Daerah, (June), 264. Retrieved from https://books. google.co.id/books/about/Handbook_Pemerintahan_Daerah.html?id=oJBiDwAAQBAJ\&redir_esc=y\%0Ahttps://www.academia. edu/36946152/Buku_HANDBOOK_PEMERINTAHAN_DAERAH\%0Ahttps://www.academia. edu/36946154/HANDBOOK_PEMERINTAHAN_DAERAH

Strauss, A., \& Corbin, J. (1994). Grounded Theory Methodology. In Handbook of Qualitative Research, 2nd Ed. (pp. 273-285).

Suharyo. (2012). Otonomi Khusus di Papua dan Aceh Sebagai Perwujudan Implementasi Peranan Hukum Dalam Kesejahteraan Masyarakat. Rechtsvinding, 1(1), 375-395.

Tarlton, C. (1965). Symmetry and Asymmetry as Elements of Federalism: A Theoretical Speculation. Journal of Politics, 27(4).

Warouw, S., Nangoy, G., Runtu, T., Akuntansi, J., Ekonomi, F., \& Ratulangi, U. S. (2016). Analisis Penggunaan Dana Otonomi Khusus Pada Pemerintah Kota Sorong Di Provinsi Papua Barat. Jurnal Berkala Ilmiah Efisiensi, 16(01), 627-637. 